\title{
CORRUPT FROM THE HEAD DOWN: HUMAN RIGHTS IMPACT OF POLITICAL FAVOURITISM IN PUBLIC PROCUREMENT
}

\section{Introduction}

dopted in 2011, the UN Guiding Principles on Business and Human Rights (UNGPs), ${ }^{1}$ represent a shift in perspective on human rights responsibilities: 1 the UNGPs introduced the business responsibility to respect human rights and compelled states to deliver on their obligations to protect human rights from abuses in the private sector. This novel approach also challenged the traditional paradigm that some areas of governance are subject to strictly economic analysis and, hence, unreceptive of social approaches, including human rights. One such area addressed by the UNGPs is the so-called state-business nexus that addresses the state's role as an economic actor. Principles 4-6 suggest that as states are primary duty holders of human rights responsibilities, they should "take additional steps" and "lead by example" in the governance of state-owned enterprises, public procurement, and privatisation, and use their position as a leverage to promote business respect for human rights. ${ }^{2}$

The UNGPs' special emphasis on state actions under the role as an economic agent is closely connected to states' primary roles and obligations. Regardless of the rules of the market that apply to economic actors, states are bound by public interests first and foremost, including the human rights of persons under its jurisdiction. Immense regulatory, policy-making and executive powers entrusted to state institutions through the social contract also necessitate special care on how these powers are exerted. Therefore, states have an unwavering and primary obligation to act in conformity with human rights norms, standards, and requirements, even when acting as an economic agent, and are accountable for any violations.

Beyond direct implications, the state's actions as an economic agent can also dictate what is permissible on the market. Acting as economic actors, states conduct business

\footnotetext{
* Ніка Аревадзе, досліАник, магістр права з міжнародного права, прав Аюдини, Університет Аунду; аспірант Університету Осло, Норвегія.

Nika Arevadze, Researcher, LLm in International Human Rights Law, Lund University; MPhiL Candidate in Theory and Practice of Human Rights, University of Oslo, Norway.

e-mail: nikaa@uio.no

ORCID ID: https://orcid.org/0000-0002-9048-4699

${ }^{1}$ UN, Human Rights Council, Guiding Principles on Business and Human Rights: Implementing the United Nations "Protect, Respect and Remedy" Framework 2011, A/HRC/17/31.

${ }^{2}$ Ibid, Principles 4-6.
} 
with business ${ }^{3}$ and, in this relationship, their actions represent an (either positive or negative) example and have a significant influence on the private sector behaviour. In other words, if the state's actions on the market do not comply strictly with its direct human rights obligations to protect, respect and fulfil, business entities are far less likely to deliver on their voluntary responsibility to respect human rights.

Public procurement is a significant aspect of the state-business nexus. It is the process where state agencies or other public entities enter the market as buyers of goods, services and works. ${ }^{4}$ Moreover, it represents a significant part of the global economy - its share in the global Gross Domestic Product (GDP) was $12 \%$ in 2018, amounting to 11 trillion USD. ${ }^{5}$ Considering the functions and volume public procurement encompasses, it has direct and indirect links with the human rights of a wide array of rightsholders. These linkages have been addressed in business and human rights scholarship, ${ }^{6}$ as well as in the works of international human rights bodies. ${ }^{7}$ However, this attention has mainly been directed towards policy and regulatory analysis of whether public procurement reflects human rights considerations and how it can be managed. Meanwhile, root governance issues that create the gap between public procurement and human rights and contribute to the lack of progress remain relatively unexplored.

This paper investigates a prevalent governance issue in public procurement - political favouritist corruption schemes ${ }^{8}$ and their role in the paradoxical lack of progress in aligning public procurement systems with human rights requirements. Whereas all types of corruption are widespread in public procurement, political favouritism often has an

\footnotetext{
${ }^{3}$ Christine Parker and John Howe, "Ruggie's Diplomatic Project and Its Missing Regulatory Infrastructure," in The UN Guiding Principles on Business and Human Rights (Brill Nijhoff, 2012), 284.

${ }^{4}$ For instance: "Public Procurement - OECD", OECD, accessed February 10, 2021, http://www.oecd.org/ governance/public-procurement/; "Public Procurement," European Commission, accessed February 10, 2021, https://ec.europa.eu/info/policies/public-procurement_en.

5 "How Large Is Public Procurement?" World bank blogs, accessed February 9, 2021, https:// blogs.worldbank.org/developmenttalk/how-large-public-procurement.

${ }^{6}$ For instance, for extensive discussion on procurement and human rights see Olga Martin-Ortega and Claire Methven O’Brien, Public Procurement and Human Rights (Edward Elgar Publishing, 2019).

${ }^{7}$ For instance, for the recent analysis see UN, Human Rights Council, Report of the Working Group on the Issue of Human Rights and Transnational Corporations and Other Business Enterprises on Connecting the Business and Human Rights and the Anticorruption Agendas, A/HRC/44/43 (2020), paras 12-13. ${ }^{8}$ While other terms have also been used to refer to concepts and effects of similar issues (Susan RoseAckerman provides terms such as "administrative corruption," "crony capitalism" and "state capture" in: Susan Rose-Ackerman, "The Challenge of Poor Governance and Corruption," DIREITO GV L. Rev. Especial 1 (2005): 207, 218). This text employs political favouritism in public procurement to denote the arrangement where companies or their owners create connections with political parties, mainly through donations, and, in return, are rewarded by public procurement contracts. See, Bruno Baranek and Vitezslav Titl, “The Cost of Favoritism in Public Procurement," FEB Research Report Department of Economics (2020); Audinga Baltrunaite, "Political Contributions and Public Procurement: Evidence from Lithuania," Journal of the European Economic Association 18 (2020): 541; Vitezslav Titl and Benny Geys, "Political Donations and the Allocation of Public Procurement Contracts," European Economic Review 111 (2019): 443.
} 
appearance of legality, is deeply embedded in the system, and penetrates high levels of government. Political favouritism entails the prioritization of private gains over public interests in public procurement and, if it takes a systemic form, it can erode public trust in government institutions and, regardless of legal consequences, damage companies' social license to operate. Finally, it also erases the traditional public-private divide and creates opportunities for corporate capture. ${ }^{9}$

Due to these factors, political favouritism in public procurement can have a negative impact on individual rights and obstruct the implementation of human rights policies in governance. Moreover, as this paper argues below, human rights integration can threaten such corrupt schemes by obstructing the regular flow of illicit funds or imposing additional transparency and oversight on procurement deals. Therefore, political favouritist schemes can be conceptualized as a fundamental roadblock for integrating human rights into public procurement.

The paper analyses relevant primary and secondary sources in the fields of business and human rights, governance, and economics and organizes the discussion as follows: section 2 discusses the links between public procurement and human rights; section 3 analyses the role of corruption in general and political favouritism in particular within public procurement; section 4 outlines the risks, impacts, and obstructive effects of political favouritist schemes for individual human rights and the human rights approach to the public procurement governance; section 5 concludes and suggests directions for further research.

\section{Public Procurement and Human Rights}

Links between human rights and public procurement, as apparent as they might seem through a systemic analysis, are rarely recognized by procurement regulations, partially due to the traditional construction of procurement systems. Public procurement is regulated by differing national or organizational rules, but similar structural elements of the process can be identified across jurisdictions. It consists of pre-bidding (decision to contract and definition of contract characteristics), bidding (contracting process and award) and post-bidding (contract implementation and monitoring) phases. ${ }^{10}$ Moreover, the primary aims guiding public procurement can be generalized as value for money, non-discrimination between tenderers, and open competition. ${ }^{11}$ Governments have

\footnotetext{
${ }^{9}$ UN, Human Rights Council, Report of the Working Group on the Issue of Human Rights and Transnational Corporations, paras $72-74$.

${ }^{10}$ Wim Wensink and Jan Maarten de Vet, "Identifying and Reducing Corruption in Public Procurement in the EU" (Made for the European Commission by $\mathrm{PwC}$ and Ecorys with support of Utrecht university, 2013), 45, https://ec.europa.eu/anti-fraud/sites/antifraud/files/docs/body/ identifying_reducing_corruption_in_public_procurement_en.pdf.

${ }^{11}$ Olga Martin-Ortega and Claire Methven O’Brien, "Public Procurement and Human Rights: Interrogating the Role of the State as Buyer," in Public Procurement and Human Rights (Edward Elgar Publishing, 2019), 5.
} 
also incorporated secondary social and environmental goals into public procurement regulations, such as combating modern slavery in the $\mathrm{UK}^{12}$ or promoting equality in South Africa, ${ }^{13}$ adopting "social," "green" or "sustainable procurement" models. ${ }^{14}$ However, such approaches remain scarce ${ }^{15}$ and, even when adopted, social and environmental goals are indeed secondary to and sidelined by the economic objectives of public procurement.

Through public procurement, states purchase a wide array of goods, works and services to carry out public functions. The material scope of public procurement can include purchasing anything from office supplies to military equipment, as well as commissioning the construction of fundamental infrastructure or ensuring the provision of public services. ${ }^{16}$ Public procurement is also linked to the wave of privatisation in recent years, through which the private sector has increasingly become responsible for activities traditionally performed by governments. ${ }^{17}$ As a result, governments purchase goods and services that they directly produced or performed in the past, including core public services, such as criminal justice, education, health and social care.

Public procurement of essential goods and services is directly linked to states' human rights obligations. The decision of what the state purchases, i.e., the substance and quality of acquired goods and services can determine whether the state fulfils its (international or national) human rights obligations, especially in the area of economic, social and cultural rights. For instance, if procured healthcare or education do not meet the qualitative standards required by the corresponding human right, the state might be found to have violated its obligation to fulfil.

Even when public procurement is not connected to the delivery of essential services, the process is linked to human rights impacts based on who the state purchases goods and services from. Companies in public procurement value chains can be involved in or linked to violations of labour rights, discrimination, environmental harm or other adverse human rights impacts. Through the doctrine of positive human rights obligations, states can be held liable for human rights violations in public procurement value chains and

\footnotetext{
${ }^{12}$ Olga Martin-Ortega, "Public Procurement as a Tool for the Protection and Promotion of Human Rights: A Study of Collaboration, Due Diligence and Leverage in the Electronics Industry," Business and Human Rights Journal 3 (2018): 75, 78.

${ }^{13}$ Geo Quinot, "Constitutionalising Public Procurement through Human Rights: Lessons from South Africa," in Public Procurement and Human Rights, eds. Olga Martin-Ortega and Claire Methven O'Brien (Edward Elgar Publishing, 2019), 78-79.

${ }^{14}$ Claire Methven O'Brien and Olga Martin-Ortega, "Human Rights and Public Procurement of Goods and Services," in Research Handbook on Human Rights and Business, eds. Surya Deva and David Birchall (Edward Elgar Publishing, 2020), 278.

${ }^{15} \mathrm{UN}$, Human Rights Council, Report of the Working Group on the Issue of Human Rights and Transnational Corporations, para 13.

${ }^{16}$ O’Brien and Martin-Ortega, "Human Rights and Public Procurement."

${ }^{17}$ UN, The Special Rapporteur on Extreme Poverty and Human Rights, Privatisation, Extreme Poverty and Human Rights, A/73/396 (2018), paras 1-2, accessed February, 11, 2021, https://www.ohchr.org/ EN/Issues/Poverty/Pages/Privatisation.aspx.
} 
respective procurement regulations and rules (or the lack thereof) can be at the centre of such scrutiny. ${ }^{18}$

Moreover, its significant share in the global and national economies makes public procurement an essential instrument to promote and secure human rights in the private sector. Through their substantial purchasing power, states hold considerable leverage on private producers and service providers to influence their social, environmental or governance policies and create demand for responsible business performance. ${ }^{19}$ On the other hand, the absence of human rights considerations in public procurement regulations, tenders and contracts might be understood by the private sector as an indication of the secondary and peripheral nature of human rights in the state agenda. In any case, state recognition of the linkages between human rights and public procurement can have significant direct and indirect impacts on stakeholders' human rights.

The significance of public procurement for human rights in business is recognized by the UN Guiding Principles on Business and Human Rights. The state duty to protect human rights under the UNGPs includes operational principles applicable to states' actions under their role as economic agent. ${ }^{20}$ These principles, united under the umbrella term "state-business nexus," include Principle 6 which stipulates that "states should promote respect for human rights by business enterprises with which they conduct commercial transactions." ${ }^{21}$ A part from the UN framework, the Organisation for Economic Co-operation and Development (OECD) has also been promoting integrating human rights, labour, gender and other social considerations into public procurement systems through the concept of Responsible Business Conduct (RBC).$^{22}$ In light of these developments, states increasingly include public procurement in their National Action Plans (NAPs) on business and human rights ${ }^{23}$ and there have been few positive examples of incorporating social and environmental considerations into public procurement regulations as secondary aims. ${ }^{24}$

However, public procurement regimes remain resistant to incorporating human rights and respective instruments, such as human rights impact assessment. O'Brien and Martin-Ortega (2018) note that, compared to the increasing expectations for the private

\footnotetext{
${ }^{18}$ Edoardo Alberto Rossi, "Human Rights Clauses in Public Procurement: A New Tool to Promote Human Rights in (States') Business Activities?” in Legal Sources in Business and Human Rights (Brill Nijhoff, 2020), 277; O’Brien and Martin-Ortega, "Human Rights and Public Procurement," 255.

${ }^{19}$ Martin-Ortega, "Public Procurement as a Tool for the Protection," 75-77.

${ }^{20}$ UNGPs Principles 4-6.

${ }^{21}$ Ibid, Principle 6.

${ }^{22}$ OECD, "1. Public Procurement - Supporting Responsible Business Conduct | Integrating Responsible Business Conduct in Public Procurement" (OECD iLibrary, 22 December 2020), accessed February 16, 2021, https://www.oecd-ilibrary.org/sites/02682b01-en/1/3/1/1/index.html?itemId=/content/ publication/02682b01-en\&_csp_=e1facecd62f7ae24f03312574370f56e\&itemIGO=oecd\&itemContent Type $=$ book.

23 "Public Procurement," National Action Plans on Business and Human Rights, accessed February 16, 2021, https://globalnaps.org/issue/public-procurement/.

${ }^{24}$ O’Brien and Martin-Ortega, "Human Rights and Public Procurement,” 278.
} 
sector, the absence of public buyers' supply chain responsibilities for human rights from legislative or policy frameworks is paradoxical. ${ }^{25}$ This divergence is surprising especially because states are the primary bearers of human rights obligations, and human rights law does not allow duty bearers to brush human rights aside. ${ }^{26}$

To explain the paradox, the existing literature discusses the prioritization of the socalled "primary" aims of public procurement. ${ }^{27}$ In other words, economic objectives such as value for money and fair competition between bidders, outweigh or stonewall social and environmental objectives. However, literature does not account for other factors that are not part of regulatory or policy frameworks but nonetheless represent a structural element of the governance of public procurement. This paper opens the discussion on the role of a prevalent practice of awarding public procurement contracts based on political favouritism and suggests that this systemic issue threatens primary and secondary aims of procurement alike. Accordingly, the next section discusses the nature and role of political favouritist corrupt schemes in public procurement systems.

\section{Political Favouritist Corrupt Schemes in Public Procurement}

With a significant impact on human rights, public procurement systems rarely reflect these links in their governance. On the other hand, public procurement systems face structural governance issues that further complicate bridging this gap. The paper argues that corruption in general and political favouritism, in particular, represent one such obstacle.

Public procurement is particularly susceptible to corruption due to a large number of funds involved, the complexity of the process, and close interactions between public officials and private sector representatives it involves. ${ }^{28}$ As a result, public procurement can entail multiple types of corruption risks that can vary depending on the procurement phase, national or institutional context, and other factors. ${ }^{29}$ Article 9 of the UN Convention against Corruption specifically addresses the issue of corruption in public procurement. ${ }^{30}$ Compared to other types, high-level institutionalized corruption is more prevalent in

\footnotetext{
${ }^{25}$ Claire Methven O’Brien and Olga Martin-Ortega, "Discretion, Divergence, Paradox: Public and Private Supply Chain Standards on Human Rights" (Social Science Research Network 2018) SSRN Scholarly Paper ID 3197615 2-3, accessed February 15, 2021, https://papers.ssrn.com/abstract=3197615.

${ }^{26}$ Ibid.

${ }^{27}$ See for instance, O’Brien and Martin-Ortega, "Human Rights and Public Procurement," 247-53.

${ }^{28}$ Preventing Corruption in Public Procurement (OECD, 2016), 6, http://www.oecd.org/gov/ethics/ Corruption-Public-Procurement-Brochure.pdf.

${ }^{29}$ On varying forms of corruption in public procurement see Tina Søreide, Corruption in Public Procurement. Causes, Consequences and Cures (Chr Michelsen Intitute, 2002), 13-19; Sope Williams-Elegbe, "Systemic Corruption and Public Procurement in Developing Countries: Are There Any Solutions?" Journal of Public Procurement (2018): 134-38; Mike Balthazar Beke, "Political Influence in Public Procurement: Balancing between Legality and Illegality" (PhD diss., Universidad Complutense De Madrid, 2017), $140-248$.

${ }^{30}$ United Nations Convention Against Corruption 2003, A/58/422, Article 9.
} 
public procurement. ${ }^{31}$ This type of corruption can often appear legal and its detection and prevention depend on "the underlying general principles" 32 of public procurement.

The practice of awarding public procurement contracts based on political favouritism fits perfectly within the definition of high-level institutionalized corruption. This involves trading mutual favours between private and public actors: in return for political contributions, businesses get government contracts, and this arrangement benefits both parties by sponsoring their respective agendas. ${ }^{33}$ The scope of this arrangement is not limited to a single institutional setting; it connects businesses, various agencies, and political party structures, and penetrates high levels of government.

The existing country-specific research provides insight into the prevalence of political favouritism in public procurement practices. For instance, 2010 data from the Czech Republic revealed that only $1.1 \%$ of all firms were registered as public contractors, whereas $12,9 \%$ of political donor firms received public contracts. ${ }^{34}$ A 2020 article studied public procurement data from Lithuania before and after the 2012 ban on corporate political donations. The findings suggested that donor companies had "a steady and unexplained higher chance of winning in procurement tenders" even in Lithuania's relatively less corrupt and strictly regulated context, whereas this gap disappeared after the ban. ${ }^{35}$ Similar patterns of allocating large portions of procurement contracts to companies that have donated to political parties have been observed in the large spectrum of countries such as, for instance, Romania, ${ }^{36}$ Hungary, ${ }^{37}$ Croatia, ${ }^{38}$ Turkey, ${ }^{39}$ Brazi ${ }^{40}$ and the US. ${ }^{41}$

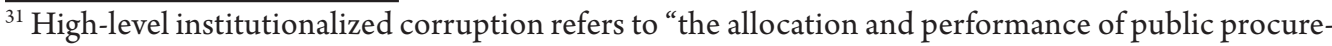
ment contracts by bending prior explicit rules and principles of good public procurement in order to benefit a closed network while denying access to all others." Mihály Fazekas and Luciana Cingolani, "Breaking the Cycle? How (Not) to Use Political Finance Regulations to Counter Public Procurement Corruption," The Slavonic and East European Review 95 (2017): 76, 80.

${ }^{32}$ Mihály Fazekas, István János Tóth, and Lawrence P. King, "Corruption Manual for Beginners: 'Corruption Techniques' in Public Procurement with Examples from Hungary," Corruption Research Center Budapest Working Paper no. CRCB-WP/2013 1 (2013): 7.

${ }^{33}$ Fazekas and Cingolani, "Breaking the Cycle?" 81.

${ }^{34}$ Titl and Geys, "Political Donations," 447.

${ }^{35}$ Baltrunaite, "Political Contributions and Public Procurement," 542-43.

${ }^{36}$ Madalina Doroftei and Valentina Dimulescu, "Corruption Risks in the Romanian Infrastructure Sector," in Government favouritism in Europe: The anticorruption report 3, ed. Alina Mungiu-Pippidi, vol. 3 (Verlag Barbara Budrich, 2015).

${ }^{37}$ Mihály Fazekas, Péter András Lukács, and István János Tóth, “The Political Economy of Grand Corruption in Public Procurement in the Construction Sector of Hungary," in Government Favouritism of Europe.

${ }^{38}$ Munir Podumljak and Elizabeth David-Barrett, "Political Favouritism in Croatian Public Procurement," in Government Favouritism in Europe.

${ }^{39}$ Uğur Emek and Muhittin Acar, "Public Procurement in Infrastructure: The Case of Turkey," in Government Favouritism in Europe.

${ }^{40}$ Taylor C. Boas, F. Daniel Hidalgo, and Neal P. Richardson, "The Spoils of Victory: Campaign Donations and Government Contracts in Brazil," The Journal of Politics 76 (2014): 415.

${ }^{41}$ Daniel Bromberg, "Can Vendors Buy Influence? The Relationship between Campaign Contributions and Government Contracts," International Journal of Public Administration 37 (2014): 556.
} 
As a rule, such practices rarely look illegal as financial transactions at the heart of this corrupt arrangement take place in the constraints of legality: neither corporate donations nor reimbursing for a procurement contract is illegal per se. As a result, this corrupt practice often goes on without detection, prevention, or other kinds of state reaction. Moreover, the exchange of donations and public contracts are not immediate and corresponding, meaning that these are part of broader schemes and systematic rather than singular quid pro quo trades. ${ }^{42}$ However, manipulation of public procurement systems is done in the shadows and requires the lack of transparency and accountability, as well as wide discretion for responsible public officials and less restrictive procurement regulations. Subsequently, contracts exempt from public procurement law, ${ }^{43}$ as well as flexibly regulated smaller contracts are more likely to be awarded to donating companies. ${ }^{44}$ However, open bidding procedures can also be exploited to favour politically connected companies through, for instance, tailoring contract specifications to donating companies or leaking information on competing bids and companies. ${ }^{45}$ Another method to ensure the smooth operation of this corrupt scheme is to decapacitate monitoring and oversight institutions and guarantee the lack of accountability. ${ }^{46}$

The practice of awarding public procurement contracts based on political favouritism violates the private-public divide that is essential to a functioning state. ${ }^{47}$ Accordingly, this arrangement violates the primary objectives of public procurement as it disrupts open competition and discriminates against bidders without political connections. At the same time, it stands against the principles of free elections and democracy by channelling illegitimate funds to campaigns of, most probably, ruling parties. However, as the next section argues, this corrupt scheme also has a significant negative impact on the population's social and economic interests.

\section{Political Favouritism in Public Procurement and Human Rights}

Aside from damaging the foundational principles of both public procurement and political system, political favouritism has more immediate costs. For such deals to remain lucrative for both parties, the price of government contracts needs to be inflated or the quality of delivered services and goods needs to be reduced below the standard. ${ }^{48}$

A 2020 study of Czech public procurement revealed that tenders allocated to politically connected firms were overpriced by at least $8 \%$, totalling a loss of 128 million USD from 2006 to $2018 .^{49}$ The study from Lithuania also estimates that cost increases in public

\footnotetext{
${ }^{42}$ Fazekas and Cingolani, "Breaking the Cycle?" 81.

${ }^{43}$ Emek and Acar, "Public Procurement in Infrastructure," 84.

${ }^{44}$ Titl and Geys, "Political Donations," 445.

${ }^{45}$ Baltrunaite, "Political Contributions and Public Procurement," 543.

${ }^{46}$ Elizabeth Dávid-Barrett and Mihály Fazekas, "Grand Corruption and Government Change: An Analysis of Partisan Favoritism in Public Procurement," European Journal on Criminal Policy and Research 1 (2019): 415.

${ }^{47}$ Fazekas and Cingolani, "Breaking the Cycle?" 82.

${ }^{48}$ Ibid, 81.

${ }^{49}$ Baranek and Titl, “The Cost of Favoritism," 3-4.
} 
procurement caused by political favouritism (more specifically, corporate donations) equals $1 \%$ of the GDP and eliminating this corrupt arrangement would save about 180 million EUR annually. ${ }^{50}$ In the meantime, higher prices do not result in increased quality of deliverables; ${ }^{51}$ rather, the diversion of public funds towards the parties in this illicit deal brings about low-quality and unsafe works, goods and services. ${ }^{52}$ Moreover, in settings where corrupt schemes are well-embedded and systemic, new procurement needs for deteriorating goods, such as repairs for infrastructure, can be exploited to maintain and further corrupt deals between politicians and businesses. As a result, political favouritism in public procurement undermines the value for money principle and diverts budgetary funds from public interests to benefit political and business elites, at the same time lowering the quality of procured goods and services.

These financial and qualitative effects of political favouritism entail negative social impacts. As favouritism is normally sustained in a homogenous group, in this case, in political elites and their loyal business counterparts, it decreases aggregate social welfare and perpetuates inequality among social groups. ${ }^{53}$ This can also hamper the growth of local businesses and decrease foreign investments that, in turn, can result in declining job opportunities, reducing tax revenues and other negative impacts on social development. ${ }^{54}$ Moreover, budgetary funds are a limited resource and often serve to secure basic public needs such as healthcare, education or basic infrastructure. Diverting as much as $1 \%$ of the GDP ${ }^{55}$ to the parties of this corrupt scheme subtracts it from the funds that could otherwise be spent for more or better-quality goods and services, proportionally lowering the amount or quality of social spending. Finally, corruption in a broad sense has been demonstrated to negatively affect life expectancy, maternal mortality, child nutrition, and education, and erode trust in state institutions. ${ }^{56}$

Negative social effects of corrupt systems often manifest in adverse impacts on specific human rights. Research on connections between corruption and human rights has been debating whether corruption can or should qualify as a human rights violation. ${ }^{57}$ However,

\footnotetext{
${ }^{50}$ Baltrunaite, "Political Contributions and Public Procurement," 579.

${ }^{51}$ Baranek and Titl, "The Cost of Favoritism," 29.

${ }^{52}$ Dávid-Barrett and Fazekas, "Grand Corruption and Government Change," 412.

${ }^{53}$ Yann Bramoullé and Sanjeev Goyal, "Favoritism," Journal of Development Economics 122 (2016): 16, 23.
}

${ }^{54}$ Wensink and Vet, "Identifying and Reducing Corruption," 63.

${ }^{55}$ Approximate estimation provided by Baltrunaite, "Political Contributions and Public Procurement," 579; David Schoenherr, "Political Connections and Allocative Distortions," The Journal of Finance 74 (2019): 543, 546.

${ }^{56}$ Angela Barkhouse, Hugo Hoyland, and Marc Limon, Corruption: A Human Rights Impact Assessment (Universal Rights Group and Kroll, 2018), 9-18, https://www.universal-rights.org/wp-content/ uploads/2018/04/Policy_report_corruption_LR.pdf.

${ }^{57}$ The exchange between Anne Peters and Franco Peirone is a perfect example of this debate. See, Anne Peters, "Corruption as a Violation of International Human Rights," European Journal of International Law 29 (2018): 1251; Franco Peirone, "Corruption as a Violation of International Human Rights: A Reply to Anne Peters," European Journal of International Law 29 (2018): 1297. 
there is a wide consensus in academia and international organizations alike that corruption is strongly linked to negative impacts on human rights encompassed by the International Bill of Human Rights. ${ }^{58}$

Corruption has been linked to negative impacts on civil and political rights, such as the right to life, equality and non-discrimination, the freedom of expression and information, the right to a fair trial and political participation rights. ${ }^{59}$ However, special attention has been given to the harm that corruption brings about on economic, social and cultural (ESC) rights, as corruption diverts critical resources to private interests. ${ }^{60}$ The examples of ESC rights threatened by corruption include the right to development, the right to health, the right to education, the right to an adequate standard of living (housing, food, water). ${ }^{61}$

Human rights impacts of political favouritism or other types of corruption in public procurement have not yet been in the centre of scholarly focus so far. However, UN human rights bodies have particularly mentioned public procurement in the discussion about corruption and human rights. A 2020 report of the Office of the United Nations High Commissioner for Human Rights (OHCHR) highlights challenges and best practices in integrating human rights into anti-corruption practices and underlines "the importance of transparency and accountability in public procurement," ${ }^{62}$ and the nexus between the private sector, negative human rights impacts and corruption. ${ }^{63}$ Another report by the UN Human Rights Advisory Committee calls on the example of transparency and equality measures in public procurement to emphasize how states can fulfil their duty to protect from adverse human rights impacts stemming from corrupt acts by the private sector. ${ }^{64}$ The latest report by the UN Working Group on Business and Human Rights also discusses corruption as a fundamental problem specifically for the business and human rights agenda and distinguishes public procurement as especially susceptible to corruption. ${ }^{65}$

\footnotetext{
${ }^{58}$ Comprising of Universal Declaration of Human Rights 1948 (UNGA Res 217 A(III)); International Covenant on Civil and Political Rights 1966 (999 UNTS 171); International Covenant on Social, Economic and Cultural Rights 1966 (993 UNTS 3).

${ }^{59}$ Corruption and Human Rights: Making the Connection (International Council on Human Rights Policy, 2009), 32-45; Barkhouse, Hoyland, and Limon, Corruption, 19-32.

${ }^{60}$ See for instance, UN, Human Rights Council, Report of the Office of the United Nations High Commissioner for Human Rights on Challenges Faced and Best Practices Applied by States in Integrating Human Rights into Their National Strategies and Policies to Fight against Corruption, Including Those Addressing Non-State Actors, Such as the Private Sector, A/HRC/44/27 (2020), paras 19-20.

${ }^{61}$ Kolawole Olaniyan, "The Implications of Corruption for Social Rights," in Research Handbook on International Law and Social Rights, eds. Christina Binder and others (Edward Elgar Publishing, 2020), 365-67; Corruption and Human Rights, 45-63; Barkhouse, Hoyland, and Limon, Corruption, 19-32. ${ }^{62}$ UN, Human Rights Council, Report of the Office of the United Nations High Commissioner for Human Rights on Challenges Faced, paras 30-31.

${ }^{63}$ Ibid, 40-49.

${ }^{64}$ UN, Human Rights Council, Final Report of the Human Rights Council Advisory Committee on the Issue of the Negative Impact of Corruption on the Enjoyment of Human Rights, A/HRC/28/73 (2015), para 9. ${ }^{65} \mathrm{UN}$, Human Rights Council, Report of the Working Group on the Issue of Human Rights and Transnational Corporations, paras 10-12.
} 
Political favouritism in public procurement can affect a wide range of rightsholders depending on, among other factors, the economic and social effect of corrupt schemes, the subject matter of the procurement contract in question, and the prevalence of such schemes in the procurement system. The most common methods employed by public officials to maintain political favouritist schemes in public procurement include (1) designing procurement contract in a manner that sidesteps preventive measures, rules, and standards; (2) guaranteeing that a connected company receives the contract regardless of a record of proven violations and poor performance; (3) ignoring violations of labour, environmental or technical standards within the contract performance and/ or decapacitating oversight mechanisms; and (4) accepting poor quality deliverables. The resulting short or long-term deficiencies, such as the loss of quality or funds can manifest into negative human rights impacts.

Bellow-standard quality of deliverables caused by corruption and diverted funds can have a direct impact on the population. For instance, inferior quality public infrastructure can collapse and result in mortalities and injuries, hence, causing negative impacts on the rights to life and health of the users. In some cases, delivery under the procurement contract concerns a basic service that falls within the scope of ESC rights, such as health and social care, education, or adequate standard of living. In such cases, the inferior quality of service is directly linked with the qualitative requirements of corresponding rights. For example, if, as a result of diverted funds, a procured healthcare service does not meet the requirements of availability, accessibility, acceptability and quality, ${ }^{66}$ the state might be found to have violated its obligations under the right to health.

Apart from the quality of delivery, poor quality of performance stemming from a corrupt scheme might also have a negative impact on rightsholders. For instance, poor oversight of a procurement contract resulting in non-compliance with labour standards can be directly linked to the poor treatment of employees of the contracting business and hence, negatively affect their labour rights. Similarly, the lack of environmental oversight on infrastructure projects can result in environmental disasters and, in turn, threaten the life and health of local populations and cause relocations.

Moreover, political favouritist schemes in public procurement divert portions of limited budgetary funds towards political and private interests which might result in unrealized or discontinued social programmes, undelivered basic services, and the absence of substantial infrastructure. Whereas this effect is a dire social issue in any case, it can also constitute a human rights violation if the goods, services and works in question are necessary for the realization of ESC rights. ${ }^{67}$ In this sense, favouritist arrangements in public procurement can

\footnotetext{
${ }^{66} \mathrm{UN}$, Committee on Economic, Social and Cultural Rights, CESCR General Comment no. 14 The Right to the Highest Attainable Standard of Health, E/C.12/2000/4 (2000), para 12, accessed February 9, 2021, https://digitallibrary.un.org/record/425041? $\ln =\mathrm{en}$.

${ }^{67}$ Anne Peters, "Corruption and Human Rights," Basel Institute on Governance Working Paper (2015): 17 .
} 
be seen as the underlying reason for the state's violation of its ESC obligations. Although, there are doctrinal and practical issues related to establishing a clear link between the lack of resources due to corruption and human rights violations, in particular with causality and attribution. ${ }^{68}$ Besides the above-mentioned linkages, some authors also indicate that political favouritism threatens the human rights of not-so-well-connected competitors that end up losing tenders ${ }^{69}$ and the political participation rights of voters who face a political reality in which candidates and parties are dependent on undue financial influence from the private sector donors. ${ }^{70}$

Beyond negative impacts on individual human rights, political favouritism in public procurement represents a larger-scale issue - it obstructs the integration of human rights considerations in the state's role as an economic agent in general and public procurement in particular and hampers the business and human rights agenda.

Procurement deals influenced by political favouritism are mainly concerned to deliver on the conditions of corrupt schemes, and other considerations, including human rights, become sidelined or ignored. Otherwise, incorporating human rights requirements into the procurement process might also result in the loss of tender or disqualification of connected companies - they are not, as a rule, strict adherents to good governance standards. Moreover, to keep a corrupt arrangement lucrative, the parties - public officials and contracted companies - have to minimize the actual costs of the contract. In this sense, increasing costs of integrating human rights due diligence (HRDD) mechanisms into projects, such as human rights impact assessment (HRIA) can be counterproductive. Even without HRDD mechanisms, integrating the human rights approach entails enhanced transparency, accountability and oversight - the very opposite of what corrupt arrangements require to successfully operate.

On the other hand, the human rights approach entails empowering rightsholders and victims of abuse and bringing their role into the centre of scrutiny. ${ }^{71}$ In public procurement, this would shift the perspective and reframe the issue of political favouritism from an abstract misappropriation of public funds into its actual negative social and economic impacts. These effects of the human rights approach, as desirable as they sound from the perspective of good governanced human right baseds, can be devastating for political favouritism schemes in public procurement. Considering that ruling or dominant political powers are the main actors in such corrupt arrangements, it is logical that these same actors would be motivated to ignore or undermine increasing calls on human rights integration within anti-corruption measures or public procurement systems.

\footnotetext{
${ }^{68}$ Peters, "Corruption as a Violation of International Human Rights," 1267-76.

${ }^{69}$ See Ondrej Blažo and Hana Kováčiková, "Right for Equal Opportunity for Fair Public Contract? Human Rights in Public Procurement," Human Rights in Public Procurement (2019): 137.

${ }^{70}$ Peters, “Corruption and Human Rights," 11.

${ }^{71}$ Ibid, 26.
} 
Furthermore, as this corrupt arrangement involves a close illicit relationship between political, public, and business elites, it erases the traditional public-private divide and enables the business sector to gain informal influence and power over state policies, including business and human rights policies. This effect referred to as corporate capture, entails that political parties and campaigns become dependent on corporate donations from procurers, and they are more likely to bend to the corporate will and allow their agendas or practices that disregard or abuse human rights, hence abandon the obligation to protect human rights under the Pillar 1 of the UNGPs. Moreover, due to its legal appearance and high-level nature, political favouritism in public procurement is often a well-known fact that eludes accountability and goes on unabated. Such blatant cases of systemic corruption can erode public trust in the state. In this case, it would affect rightsholders' trust in the state's ability to uphold their interests and protect them against human rights abuses by the private sector.

\section{Conclusion}

It is evident that public procurement has significant human rights implications and, therefore, its processes requires effective safeguards to avoid negative impacts on stakeholders' human rights. Despite this simple logic, procurement systems remain resistant to increasing pressures from international organizations and frameworks, such as the UNGPs. This paper demonstrates that, apart from the traditional divide between economic and social areas of influence in governance, the described divergence is also perpetuated by unseen structural factors eroding governance. Such fundamental issues, exemplified in the paper by political favouritist schemes of corruption, create illicit norms and rules that clash with good governance principles and harm primary, as well as secondary objectives of public procurement.

The adverse loop of political favouritism, public procurement and human rights impacts has been scarcely addressed on political or academic levels, and, hence, there is no evidence for successful mechanisms for combating this specific type of corruption. However, the general issue of corruption in public procurement is analysed in the latest report of the UN Working Group on Business and Human Rights ${ }^{72}$ which reviews existing anti-corruption measures that can alleviate negative human rights impacts. These measures include the integration of human rights as a condition for awarding procurement contracts, excluding bidders based on their record of corruption and human rights violations, integrating human rights and anti-corruption considerations in supply chain codes of conduct, integrity pacts, ${ }^{73}$ employing modern technology such as digitalized procurement or block-chain

\footnotetext{
${ }_{72} \mathrm{UN}$, Human Rights Council, Report of the Working Group on the Issue of Human Rights and Transnational Corporations.

${ }^{73}$ The Report defines integrity pacts as a process " 82 in which a contracting authority and bidders agree to comply with best practice and maximum transparency, and a third party, often a civil society organization, monitors the procurement process against those commitments," para 39.
} 
based systems ${ }^{74}$ and strong conflict of interest laws. ${ }^{75}$ Scholarly literature has also offered to align the human rights based approach and anti-corruption measures to effectively address the human rights impacts of corruption. ${ }^{76}$ However, there is a scarcity of systemic analysis or empirical evidence on the human rights based-approach to anti-corruption or aligning these two areas of governance.

While this paper explores the links between corruption, governance, procurement, business and human rights, it barely scratches the surface of this complex issue. This demonstrates that there is a need for further research focusing on deeper analysis of human rights impacts, good governance measures, public procurement systems, and, most importantly, empirical evidence. Whereas the problem in this paper would benefit from the analysis from different fields of study such as governance, economics, law, and human rights, the interdisciplinary methods of business and human rights scholarship would be the perfect fit to analyse its multidimensional nature. At the same time, the business and human rights agenda needs to address the root causes of the lack of progress in leveraging the state's role as an economic agent in advancing human rights. ${ }^{77}$ The intersection of the dark side of politics, structural issues of public procurement and resulting human rights impacts is a perfect place to start.

(C) N. Arevadze, 2021

\section{Bibliography}

Balthazar Beke, Mike. "Political Influence in Public Procurement: Balancing between Legality and Illegality.” PhD diss., Universidad Complutense De Madrid, 2017.

Baltrunaite, Audinga. "Political Contributions and Public Procurement: Evidence from Lithuania." Journal of the European Economic Association 18 (2020).

Baranek, Bruno, and Titl Vitezslav. “The Cost of Favoritism in Public Procurement.” FEB Research Report Department of Economics, 2020.

Barkhouse, Angela, Hugo Hoyland, and Marc Limon. Corruption: A Human Rights Impact Assessment. Universal Rights Group and Kroll, 2018. https://www.universal-rights.org/wp-content/ uploads/2018/04/Policy_report_corruption_LR.pdf.

Blažo, Ondrej, and Hana Kováčiková. "Right for Equal Opportunity for Fair Public Contract? Human Rights in Public Procurement." Human Rights in Public Procurement (2019).

Boas, Taylor C., F. Daniel Hidalgo, and Neal P. Richardson. "The Spoils of Victory: Campaign

Donations and Government Contracts in Brazil.” The Journal of Politics 76 (2014).

Bramoullé, Yann, and Goyal Sanjeev. “Favoritism.” Journal of Development Economics 122 (2016).

${ }^{74} \mathrm{UN}$, Human Rights Council, Report of the Working Group on the Issue of Human Rights and Transnational Corporations, paras 36-39.

${ }^{75}$ Ibid, $72-47$.

${ }^{76}$ Peters, "Corruption and Human Rights," 26-27; Peters, "Corruption as a Violation of International Human Rights," 1276-78.

${ }^{77}$ UN, Human Rights Council, Report of the Working Group on the Issue of Human Rights and Transnational Corporations, para 13. 
Bromberg, Daniel. "Can Vendors Buy Influence? The Relationship between Campaign Contributions and Government Contracts." International Journal of Public Administration 37 (2014).

Corruption and Human Rights: Making the Connection. International Council on Human Rights Policy, 2009.

Dávid-Barrett, Elizabeth, and Mihály Fazekas. "Grand Corruption and Government Change: An Analysis of Partisan Favoritism in Public Procurement.” European Journal on Criminal Policy and Research 1 (2019).

Doroftei, Madalina, and Valentina Dimulescu. "Corruption Risks in the Romanian Infrastructure Sector." In Government favouritism in Europe: The anticorruption report 3, edited by Alina MungiuPippidi, vol. 3. Verlag Barbara Budrich, 2015.

Emek, Ugur, and Muhittin Acar. "Public Procurement in Infrastructure: The Case of Turkey." In Government Favouritism in Europe: The Anticorruption Report3, edited by Alina Mungiu-Pippidi. Verlag Barbara Budrich, 2015.

Fazekas, Mihály, and Luciana Cingolani. "Breaking the Cycle? How (Not) to Use Political Finance Regulations to Counter Public Procurement Corruption," The Slavonic and East European Review 95 (2017).

Fazekas, Mihály, István János Tóth, and King Lawrence P. “Corruption Manual for Beginners: 'Corruption Techniques' in Public Procurement with Examples from Hungary." Corruption Research Center Budapest Working Paper no. CRCB-WP/2013 1 (2013).

Fazekas, Mihály, Péter András Lukács, and Tóth István János. “The Political Economy of Grand Corruption in Public Procurement in the Construction Sector of Hungary.” In Government Favouritism of Europe: The Anticorruption Report 3, edited by Alina Mungiu-Pippidi. Verlag Barbara Budrich, 2015.

Guiding Principles on Business and Human Rights: Implementing the United Nations "Protect, Respect and Remedy" Framework 2011, A/HRC/17/31.

“How Large Is Public Procurement?” World bank blogs. Accessed February 9, 2021. https:// blogs.worldbank.org/developmenttalk/how-large-public-procurement.

Martin-Ortega, Olga. "Public Procurement as a Tool for the Protection and Promotion of Human Rights: A Study of Collaboration, Due Diligence and Leverage in the Electronics Industry." Business and Human Rights Journal 3 (2018).

Martin-Ortega, Olga, and Claire Methven O’Brien. Public Procurement and Human Rights. Edward Elgar Publishing, 2019.

Martin-Ortega, Olga, and O’Brien Claire Methven. "Public Procurement and Human Rights: Interrogating the Role of the State as Buyer." In Public Procurement and Human Rights. Edward Elgar Publishing, 2019.

O’Brien, Claire Methven, and Olga Martin-Ortega. "Discretion, Divergence, Paradox: Public and Private Supply Chain Standards on Human Rights” (Social Science Research Network 2018) SSRN Scholarly Paper ID 3197615 2-3. Accessed February 15, 2021. https://papers.ssrn.com/ abstract $=3197615$. 
O’Brien, Claire Methven, and Olga Martin-Ortega. "Human Rights and Public Procurement of Goods and Services." In Research Handbook on Human Rights and Business, edited by Surya Deva and David Birchall. Edward Elgar Publishing, 2020.

OECD, '1. Public Procurement - Supporting Responsible Business Conduct | Integrating Responsible Business Conduct in Public Procurement' (OECD iLibrary, 22 December 2020). Accessed February 16, 2021. https://www.oecd-ilibrary.org/sites/02682b01-en/1/3/1/1/index.html?itemId=/ content/publication/02682b01-en\&_csp_=e1facecd62f7ae24f03312574370f56e\&itemIG$\mathrm{O}=$ oecd\&itemContent Type $=$ book.

Olaniyan, Kolawole. “The Implications of Corruption for Social Rights.” In Research Handbook on International Law and Social Rights, edited by Christina Binder and others. Edward Elgar Publishing, 2020.

Parker, Christine, and John Howe. "Ruggie's Diplomatic Project and its Missing Regulatory Infrastructure." In The UN Guiding Principles on Business and Human Rights. Brill Nijhoff, 2012.

Peirone, Franco. "Corruption as a Violation of International Human Rights: A Reply to Anne Peters." European Journal of International Law 29 (2018).

Peters, Anne. "Corruption and Human Rights." Basel Institute on Governance Working Paper (2015). Peters, Anne. “Corruption as a Violation of International Human Rights.” European Journal of International Law 29 (2018).

Podumljak, Munir, and Elizabeth David-Barrett. "Political Favouritism in Croatian Public Procurement." In Government Favouritism in Europe: The Anticorruption Report 3, edited by Alina Mungiu-Pippidi. 2015.

Preventing Corruption in Public Procurement (OECD, 2016). http://www.oecd.org/gov/ethics/ Corruption-Public-Procurement-Brochure.pdf.

"Public Procurement," European Commission. Accessed February 10, 2021. https://ec.europa.eu/ info/policies/public-procurement_en.

"Public Procurement." National Action Plans on Business and Human Rights. Accessed February 16, 2021. https://globalnaps.org/issue/public-procurement/.

"Public Procurement - OECD," OECD. Accessed February 10, 2021. http://www.oecd.org/ governance/public-procurement/.Quinot, Geo. "Constitutionalising Public Procurement through Human Rights: Lessons from South Africa." In Public Procurement and Human Rights, edited by Olga Martin-Ortega and Claire Methven O’Brien. Edward Elgar Publishing, 2019.

Rose-Ackerman, Susan. "The Challenge of Poor Governance and Corruption.” DIREITO GV L. Rev. Especial 1 (2005).

Schoenherr, David. "Political Connections and Allocative Distortions." The Journal of Finance 74 (2019).

Søreide, Tina. Corruption in Public Procurement. Causes, Consequences and Cures. Chr Michelsen Intitute, 2002.

The Special Rapporteur on Extreme Poverty and Human Rights, "Privatisation, Extreme Poverty and Human Rights” (2018) A/73/396. Accessed February 11, 2021. https://www.ohchr.org/ EN/Issues/Poverty/Pages/Privatisation.aspx. 
Titl, Vitezslav, and Benny Geys. "Political Donations and the Allocation of Public Procurement Contracts." European Economic Review 111 (2019).

UN, Committee on Economic, Social and Cultural Rights, CESCR General Comment no. 14 The Right to the Highest Attainable Standard of Health, E/C.12/2000/4 (2000). Accessed February 9, 2021. https://digitallibrary.un.org/record/425041? ln=en.

UN, Human Rights Council, Final Report of the Human Rights Council Advisory Committee on the Issue of the Negative Impact of Corruption on the Enjoyment of Human Rights, A/HRC/28/73 (2015).

UN, Human Rights Council, Guiding Principles on Business and Human Rights: Implementing the United Nations "Protect, Respect and Remedy" Framework 2011, A/HRC/17/31.

UN, Human Rights Council, Report of the Office of the United Nations High Commissioner for Human Rights on Challenges Faced and Best Practices Applied by States in Integrating Human Rights into Their National Strategies and Policies to Fight against Corruption, Including Those Addressing Non-State Actors, Such as the Private Sector, A/HRC/44/27 (2020).

UN, Human Rights Council, Report of the Working Group on the Issue of Human Rights and Transnational Corporations and Other Business Enterprises on Connecting the Business and Human Rights and the Anticorruption Agendas, A/HRC/44/43 (2020).

UN, The Special Rapporteur on Extreme Poverty and Human Rights, Privatisation, Extreme Poverty and Human Rights, A/73/396 (2018). Accessed February, 11, 2021. https://www.ohchr.org/ EN/Issues/Poverty/Pages/Privatisation.aspx.

Wensink, Wim, and Jan Maarten de Vet. "Identifying and Reducing Corruption in Public Procurement in the EU" (Made for the European Commission by $\mathrm{PwC}$ and Ecorys with support of Utrecht university, 2013). https://ec.europa.eu/anti-fraud/sites/antifraud/files/docs/body/ identifying_reducing_corruption_in_public_procurement_en.pdf.

Williams-Elegbe, Sope. "Systemic Corruption and Public Procurement in Developing Countries: Are There Any Solutions?” Journal of Public Procurement (2018).

Ніка Аревадзе. Корупція з гомови: впмив помітичного фаворитизму на права мюдини в Аержавних закупівцях

Анотація. Аержавні закупівлі становлять значну частину світової економіки та впливають на характер і якість суспільних благ та послуг. Отже, мають значні прямі та непрямі зв'язки з правами Аюдини. Проте системи державних закупівель рідко відображають ці зв'язки і залишаються “глухими” до закликів з боку міжнародних організацій та наукових досліджень щодо інтеграції прав Аюдини. Хоча це питання часто обговорюється загалом, але воно все ж залишається неАостатньо вивченим в аспекті управління, які створює розрив між державними закупівцями та правами мюдини і сприяє віАсутності прогресу. У статті досліАжується питання щодо управління у сфері державних закупівель, зокрема корупційні схеми політиків та їхня роль у парадоксальній віАсутності прогресу у приведенні систем державних закупівель у віАповіАність Ао вимог прав ^юдини. Аналізуючи первинні та вторинні Ажерела, продемонстровано зв’язки між корупційною практикою та поширеними проблемами прав ^юАини у Аержавних закупівцях. СтверАжується, що піАриваючи системи Аержавних закупівель, політична фаворитизація ставить піА загрозу первинні економічні та вторинні соціальні цілі закупівель і спричиняє несприятливі насліАки Аля прав АюАини. Ці насліАки завАають шкоАи громаАянським і політичним, а також економічним, 
соціальним і культурним правам мюдини у національному контексті зокрема та перешкоджають розвитку загалом. Крім того, ця корупційна домовценість $є$ перешкодою Аля сприяння інтеграції прав АюАини у сферу державних закупівель, а отже, гальмує прогрес у новому піАході Керівних принципів ООН з питань бізнесу і прав Аюдини, а також положень, що стосуються зв'язку між Аержавою та бізнесом. Висвітлюючи необхідність подальших міждисциплінарних та емпіричних АосліАжень, які вивчатимуть це питання з точки зору бізнесу та прав АюАини, запропоновано системний анаміз першопричин, стану та потенційних рішень.

Кмючові слова: державні закупівлі; бізнес; права Аюдини; Керівні принципи ООН з питань бізнесу і прав мюдини; корупція; фаворитизм; управління.

\section{Ника Аревадзе. Коррупция с гомовы: вАияние помитического фаворитизма на права чемовека в государственных закупках}

Аннотация. Государственные закупки составцяют значительную часть мировой экономики и влияют на характер и качество общественных благ и услуг. Итак, имеют значительные прямые и косвенные связи с правами человека. ОАнако системы государственных закупок реАко отражают эти связи и остаются “гмухими” к призывам со стороны межАународных организаций и научных исследований по интеграции прав человека. Хотя этот вопрос часто обсужАается в общем, но он все же остается недостаточно изученным в аспекте управления, создает разрыв межАу государственными закупками и правами человека и способствует отсутствию прогресса. В статье исследуется вопрос по управлению в сфере государственных закупок, в частности коррупционные схемы политиков и их роль в парадоксальном отсутствии прогресса в приведении систем государственных закупок в соответствие с требованиями прав человека. Анализируя первичные и вторичные источники, продемонстрировано связи межАу коррупционной практикой и распространенными проблемами прав человека в государственных закупках. УтвержАается, что, подрывая системы государственных закупок, политическая фаворитизация ставит под угрозу первичные экономические и вторичные социальные цеми закупок и вызывает неблагоприятные послеАствия Аля прав человека. Эти послеАствия наносят ущерб гражАанским и политическим, а также экономическим, социальным и культурным правам человека в национальном контексте в частности и препятствуют развитию в целом. Кроме того, эта коррупционная Аоговоренность явцяется препятствием Аля содействия интеграции прав человека в сферу государственных закупок, а следовательно, тормозит прогресс в новом подходе Руководящих принципов ООН по вопросам бизнеса и прав человека, а также положений, касающихся связи межАу государством и бизнесом. Освещая необходимость Аальнейших межАисциплинарных и эмпирических исследований, которые будут изучать этот вопрос с точки зрения бизнеса и прав человека, преАложено системный анализ первопричин, состояния и потенциальных решений.

Кмючевые слова: государственные закупки; бизнес; права человека; Руководящие принципы ООН по вопросам бизнеса и прав человека; коррупция; фаворитизм; управления.

\section{Nika Arevadze. Corrupt from the Head Down: Human Rights Impacts of Political Favouritism in Public Procurement}

Abstract. Public procurement represents a significant part of the global economy and influences the nature and quality of public goods and services. Consequently, it has substantial direct and indirect links with the human rights of a wide array of rightsholders. However, public procurement systems rarely reflect these links and remain resistant to calls on human rights integration from international organizations and academic scholarship. While this divergence is often discussed, the root governance 
issues that create the gap between public procurement and human rights and contribute to the lack of progress remain relatively unexplored. This paper investigates a prevalent governance issue in public procurement - political favouritist corruption schemes - and their role in the paradoxical lack of progress in aligning public procurement systems with human rights requirements. Through the analysis of primary and secondary sources, the paper demonstrates the links between such corrupt practices and prevalent human rights issues in public procurement. It argues that by undermining public procurement systems, political favouritism jeopardizes primary economic and secondary social objectives of procurement and brings about adverse human rights impacts. These impacts harm civil and political, as well as economic, social and cultural human rights in national contexts and obstruct the development at large. Moreover, this corrupt arrangement represents a roadblock for promoting human rights integration in public procurement and, hence, hampers the progress for the novel approach of the UN Guiding Principles on Business and Human Rights in general, and its provisions concerning the state-business nexus in particular. The paper concludes by outlining the need for further interdisciplinary and empirical research which will explore this issue through the lens of business and human rights, and offer a systemic analysis of root causes, the state of play and potential solutions.

Keywords: public procurement; business; human rights; UNGPs; corruption; favouritism; governance.

ОАержано/Received 10.03.2021 